\title{
POLA LITERASI VISUAL INFOGRAFER DALAM PEMBUATAN INFORMASI GRAFIS (INFOGRAFIS)
}

\author{
Muthiah Nurul Miftah ${ }^{1}$, Edwin Rizal ${ }^{2}$, Rully Khairul Anwar ${ }^{3}$ \\ ${ }^{1,2,3}$ Program Studi Ilmu Perpustakaan Universitas Padjadjaran \\ ${ }^{1}$ muthiahnurulm@gmail.com, ${ }^{2}$ edwinrizal@unpad.ac.id, ${ }^{3}$ rkha.fikom@gmail.com
}

\begin{abstract}
The purpose of this study is to find out visual literacy pattern of infographic designers in order to create infographics in House of Infographics (HOI). The scope of this study is the ability of infographic designers in interpreting the visual object and creating infographics. This study is using qualitative case study method. Observation, interview and literature study, with the purposive sampling technique are chosen as the method of data collection. The informants of the research was the designer of infographics in House of Infographics (HOI). The results of the study showed that visual literacy patterns formed in interpreting visual objects in $\mathrm{HOI}$, by reading and understanding the basic concepts of design. In creating infographics, infographic designer has workflows, which are brainstorming activities, information and data collection, content determination, narrative preparation, information visualization design, and infographics publication.
\end{abstract}

Keywords: Infographics, visual literary, information design

ABSTRAK - Penelitian ini bertujuan untuk menemukan pola literasi visual infografer dalam pembuatan informasi grafis di House of Infographics (HOI). Ruang lingkup penelitian ini ialah kemampuan desainer infografer dalam menafsirkan objek visual dan menciptakan infografis. Penelitian ini menggunakan metode studi kasus kualitatif melalui observasi, wawancara dan studi pustaka, dengan teknik purposive sampling dipilih sebagai metode pengumpulan data. Informan penelitian adalah perancang infografis di House of Infografis (HOI). Hasil penelitian menunjukkan bahwa pola literasi visual yang terbentuk dalam menafsirkan objek visual di HOI melalui membaca dan memahami konsep dasar desain. Dalam menciptakan infografis, desainer infographic memiliki alur kerja, yang brainstorming kegiatan, informasi dan pengumpulan data, penentuan konten, persiapan narasi, desain informasi visualisasi, dan publikasi infografis.

Kata kunci: Infografis, visual sastra, desain informasi

\section{PENDAHULUAN}

Infografis merupakan sebuah konsep umum penyajian informasi yang dalam penerapannya didasari oleh kreatifitas, keindahan (daya tarik), ketepatan isi dengan ilustrasi, serta keefektifan waktu yang diperlukan dalam menginterpretasikan informasi. Penggunaan infografis telah banyak dilakukan dalam penyajian informasi, hal ini dikarenakan infografis dapat menyederhanakan informasi yang sifatnya begitu kompleks menjadi informasi yang dapat dengan mudah dipahami, infografis juga mampu menarik perhatian berbagai macam kalangan masyarakat, penerapan informasi dalam bentuk infografis juga memiliki keunggulan karena dapat dengan mudah diingat.

Dengan banyaknya data yang tersebar saat ini, serta mobilitas dan kesenjangan masyarakat yang tinggi, menyebabkan terciptanya pula kesenjangan antara jumlah informasi yang masuk dengan langkanya kesempatan audiens untuk 
menyerap informasi. Penjelasan

mengenai akses informasi tersebut, dapat ditekankan dan diminimalisir dampaknya dengan pemilihan media penyebarluasan informasi yang tepat, dengan pemilihan media yang sesuai serta keterjangkauan segmentasi pembaca terhadap sebuah informasi dapat menentukan keefektifitasan dari penyebarluasan sebuah informasi, maka hal tersebut dapat dinilai dari bagaimana si penyampai informasi tersebut menggunakan keterampilannya dalam mencari dan menyampaikan informasi. Informasi dapat diperoleh oleh masing masing individu baik secara sengaja ataupun tidak sengaja. Sayangnya banyak masyarakat yang tidak memiliki waktu yang cukup lama dalam menginterpretasikan sebuah informasi, hal ini dikarenakan pada zaman sekarang umumnya masyarakat yang tinggal di kota kota besar memiliki banyak kepentingan dan terus menerus diburu oleh waktu, selain itu seperti yang kita ketahui bersama bahwa seorang individu tidak memiliki minat yang cukup lama terhadap objek ataupun bahan bacaan yang sedang dilihatnya.

Saat ini infografis mulai sedang berkembang di indonesia. Infografis sering disebut pula sebagai ilustrasi informasi (Glasgow, 1994). Infografis yang dikenal masyarakat sekarang ini lebih memfokuskan diri kepada bentuk penyampaian informasi yang disajikan melalui grafik ataupun data statistik, namun sebenarnya infografis dalam hal ini juga mencakup beberapa komponen mendasar yang pada umumnya terdapat dalam karya desain, diantaranya adalah ; gambar, pemilihan warna, pemilihan simbol yang digunakan dan bagaimana komposisi warna dan bentuk yang digunakan agar informasi yang disajikan dapat terlihat menarik dan memenuhi kriteria standar visualisasi yang dibutuhkan masyarakat.

Dalam hal ini peranan infografer sangat penting, yakni dalam mengelola informasi yang sifatnya tekstual dan kompleks agar dapat terlihat menarik dan dipahami dengan mudah oleh masyarakat luas. Kerena sejatinya informasi yang sifatnya lebih ke arah tekstual yang cenderung merepresentasikan secara panjang lebar dan sangat kompleks lebih sulit untuk dipahami, daripada informasi yang mengarah kepada bentuk representasi visual dari sebuah informasi. Dalam rangkaian infografis, infografer juga dituntut untuk memiliki keterampilan dalam menyusun komposisi konten yang akan ditampilkan dalam sebuah tema infografis, biasanya karakter dari konten yang disajikan dalam sebuah infografis memiliki sifat edukatif dan informatif, bahkan juga memiliki sifat persuasiv.

Literasi visual merupakan sebuah proses yang berkesinambungan yang dapat menumbuhkan pengetahuan yang dimiliki oleh masyarakat dan infografer mengenai cara menerjemahkan ataupun menciptakan pesan pesan visual secara tepat dan relevan dengan informasi tekstual yang ada. Masyarakat dewasa ini telah banyak diberikan simulasi simulasi sederhana mengenai informasi yang bersifat visual seperti contoh; simbol simbol ataupun logo yang ada di sekitar lingkungan kita seperti logo perusahaan, ataupun informasi informasi yang 
berbentuk visual yang terdapat dalam buku, majalah, komik, brosur, pamflet dan sebagainya.

Dengan pertimbangan bahwa masyarakat telah mendapatkan stimulus visual secara sederhana di lingkungan sekitar, maka saat ini banyak lembaga ataupun perusahaan yang sering menggunakan jasa infografer dalam mendeskripsikan sebuah informasi yang sifatnya penting, dan kompleks yang dibutuhkan oleh suatu perusahaan. Ataupun ada juga perusahaan yang memanfaatkan jasa infografer untuk meningkatkan citra sebuah perusahaan dengan cara menggunakan infografis sebagai media dalam meningkatkan promosi perusahaan. Sejalan dengan perkembangan zaman, saat ini banyak dibutuhkan jasa infografer dalam pembuatan infografis, oleh sebab itu dewasa ini banyak muncul komunitas ataupun bisnis jasa pembuatan infografis yang sedang berkembang di Indonesia salah satunya adalah lembaga "House of Infographics" yang menyediakan jasa pembuatan infografis bagi lembaga, perusahaan, media cetak dan lain sebagainya. Dengan kata lain infografer saat ini menjadi salah satu profesi yang sedang diperlukan baik dalam segi penyampaian berita ataupun dalam penyampaian informasi yang sifatnya komersial.

Berdasarkan pemaparan di atas, maka fokus penelitian disini dimaksudkan sebagai langkah awal dalam mengumpulkan data di lapangan, hal ini dilakukan sebagai dasar ataupun landasan dalam melakukan penelitian. Hasil yang dicapai dari penelitian ialah:
1. Untuk mengetahui kegiatan infografer dalam menafsirkan objek visual di House of Infogrphics?

2. Untuk mengetahui infografer menciptakan rangkaian informasi grafis (infographics) di House of Infographics?

\section{TINJAUAN PUSTAKA}

Pola merupakan serangkaian bentuk ataupun struktur yang merupakan sebuah sistem yang terjadi pada suatu keadaan yang terus menerus dilakukan oleh seseorang ataupun sekelompok orang. Pola adalah bentuk atau model (atau lebih abstrak, suatu set pengatur) yang bisa dipakai untuk membuat atau untuk menghasilkan suatu bagian dari sesuatu, khususnya jika sesuatu yang ditimbulkan cukup mempunyai alur metode yang sejenis yang nantinya dapat terlihat dan dapat dijadikan sebagai acuan atau patokan dalam suatu standar kegiatan (Iriantara, 2009).

Literasi secara umum memiliki artian berupa keberaksaraan dimana seorang individu memiliki kemahiran dalam membaca dan menulis. Dengan kata lain literasi merupakan sebuah proses belajar yang dapat menjadikan seorang individu yang pada awalnya tidak mengetahui menjadi individu yang memiliki keterampilan merepresentasikan sekaligus menggunakan objek yang dipelajarinya dalam mendukung kegiatannya dalam menciptakan dan mempresentasikan (Iriantara, 2009). Saat ini konsep literasi tidak hanya digunakan sebagai kegiatan pembelajaran secara formal seperti yang dilakukan di sekolah, universitas ataupun lembaga pendidikan lainnya, namun juga dapat 
dipakai dalam cakupan wilayah yang lebih luas dan dapat dengan mudah kita sadari seperti halnya dalam melaksanakan aktifitas sehari hari.

Sehingga pola literasi disini merupakan bentuk atau struktur yang terjadi pada suatu keadaan yang terus menerus yang dilakukan oleh sekelompok orang dalam melakukan serangkaian pembelajaran mulai dari tahapan menerima dan membaca hingga tahapan menciptakan. Dalam hal ini pengetahuan yang dimiliki seseorang sangat berpengaruh dalam kegiatan literasi, karena literasi akan terus terbangun tidak hanya didasari pada kemampuan membaca dalam aspek lisan, namun juga bagaimana dan sejauh mana seseorang dapat memahami dan merepresentasikan apa yang telah diperolehnya. Dalam proses literasi visual terdapat dua pokok utama yang mendasari rangkaian aktifitas literasi, yakni proses input dan proses output. Input dalam hal ini dapat diartikan sebagai proses penerimaan yang dilakukan oleh setiap individu dalam mempelajari sesuatu, dapat dikatakan sebagai aktifitas pertama dalam kegiatan pembelajaran, yakni membaca dan menginterpretasikan. Sedangkan output lebih kepada apa yang dihasilkan dalam proses yang didapatkan dari kegiatan input. Dalam aktivitas literasi visual, masing masing individu memiliki representasi yang berbeda beda tergantung dari bagaimana pengalaman seseorang dalam memaknai objek yang telah dilihatnya pada masa lalu. Seperti yang dijelaskan oleh Heinich Literasi visual merupakan kemampuan yang dapat dipelajari untuk menafsirkan objek visual secara tepat serta menciptakan objek visual (Glasgow, 1994).

Desain dalam artian dasar merupakan bentuk dari kegiatan perancangan. Pada kehidupan sehari hari umumnya produk dari suatu kegiatan desain dapat kita nikmati, tidak terbatas pada produk fisik yang nampak tapi juga dapat kita peroleh dari berbagai media elektronik yang dapat dengan mudah kita arahkan keberadaannya. Hakikat dari keberadaan desain merupakan hasil upaya dari rangkaian pemecahan masalah yang didalamnya terdapat dua hal penting, yaitu proses dan konsep.

Proses dalam hal ini merupakan kegiatan berpikir untuk membentuk sesuatu dengan menggabungkan fakta, konstruksi, fungsi dan estetika. Sedang konsep adalah kegiatan dan aktifitas dalam memecahkan fenomena bentuk, bahan, teknik, rupa, dan fungsi guna dinyatakan dalam bentuk baru berupa gambar. Jadi, pada hakikatnya, sebuah desain merupakan proses yang dimulai dari panggilan ide, memilih, dan menyusun elemen dasar, bentuk, bahan, sampai pada tahap pemecahan masalah yang nantinya diciptakan kembali menjadi suatu tatanan atau susunan bentuk yang harmonis, estetis, dan komunikatif. Dalam penerapannya, desain terbagi menjadi tiga (3) kategori dasar yaitu: a.) Persuasion Design b.) Instruction Design c.) Information Design (Petterson, 2012).

Lidman dan Lund berpendapat bahwa keuntungan dari sajian informasi yang ditampilkan dalam hasil dari proses desain informasi merupakan kesatuan dari kata, gambar dan grafis yang saling berhubungan dan memiliki 
keterkaitan satu sama lain, dalam dasarnya penelitian yang dilakukan akan memberitahukan sebuah pesan agar dapat dengan mudah tersampaikan dan dimengerti oleh para pembaca (Petterson, 2012). Pengembangan dalam perancangan infografis belum memiliki landasan teori khusus, umumnya pengembangan perancangan infografis diarahkan sesuai dengan beberapa teori yang dapat dijadikan sebagai acuan dasar dalam perancangan infografis, diantaranya : teori mengenai desain informasi, visualisasi data, ilmu informasi dan perpustakaan, ilmu filsafat, ilmu marketing, serta ilmu komunikasi (Petterson, 2012). Hal inilah yang menyebabkan kualitas dari perancangan infografis sangat bervariasi. Infografis awalnya merupakan kependekan dari "grafis informasi", dalam penerapannya infografis dapat diartikan sebagai format unik yang telah digunakan secara luas yang dicirkan dengan menampilkan ilustrasi, tipografi, dan orientasi horizontal maupun vertikal yang nantinya akan menampilkan fakta dari serangkaian informasi (Lankow \& Ritchie, 2014).

\section{METODE PENELITIAN}

Metode penelitian yang digunakan oleh peneliti dalam melakukan penelitian mengenai topik yang akan dikaji yaitu dengan menggunakan metode penelitian kualitatif deskriptif dengan menggunakan metode pendekatan studi kasus. Penelitian studi kasus merupakan suatu penelitian yang dilakukan secara intensif, terperinci dan mendalam terhadap suatu organisasi, lembaga ataupun gejala tertentu. Metode penelitian ini dipilih karena pada membahas suatu fase spesifik yang dilakukan oleh sekelompok ataupun beberapa orang individu yang akan dijadikan sebagai objek penelitian dalam hal ini adalah "Infografer" (Wicandra, 2001).

Dalam hal ini peneliti juga memakai metode tersebut karena bertujuan untuk menjawab berbagai fenomena yang terjadi dalam proses pengumpulan data yang berhubungan dengan faktor yang dijadikan sebagai fokus penelitian, yakni mengenai bagaimana pola aktivitas literasi visual yang terjadi pada para infografer, penafsirkan ataupun identifikasi stimulus yang berada dilingkungan sekitar, penentuan sumber data yang cocok dengan topik yang telah ditentukan, pemilihan data ataupun informasi yang relevan dengan topik yang dipilih, pola seleksi dan organisir informasi, penciptaan infografis yang menarik dan memiliki konten yang jelas dan padat, bagaimana seorang infografer mempresentasikan hasil karya yang dihasilkan yang dalam hal ini berupa infografis kepada para pembaca, serta mengevaluasi hasil karya infografisnya agar dapat meningkatkan kualitas dari hasil karya yang telah diciptakan, serta tinjauan ulang masukan dan penilaian yang telah diberikan.

Dalam penerapan metode studi kasus itu sendiri menurut Robert Yin dalam Moleong, merupakan salah satu strategi yang tepat yang digunakan ataupun dimanfaatkan dalam menjawab penelitian yang berkaitan dengan faktor "how" atau "why". karena dalam penelitian studi kasus suatu persoalan akan 
dibahas dan dijelaskan secara lebih spesifk dan tentunya juga akan meningkatkan kejelasan dari suatu persoalan yang awal mulanya merupakan persoalan yang kompleks (Moleong, 2007).

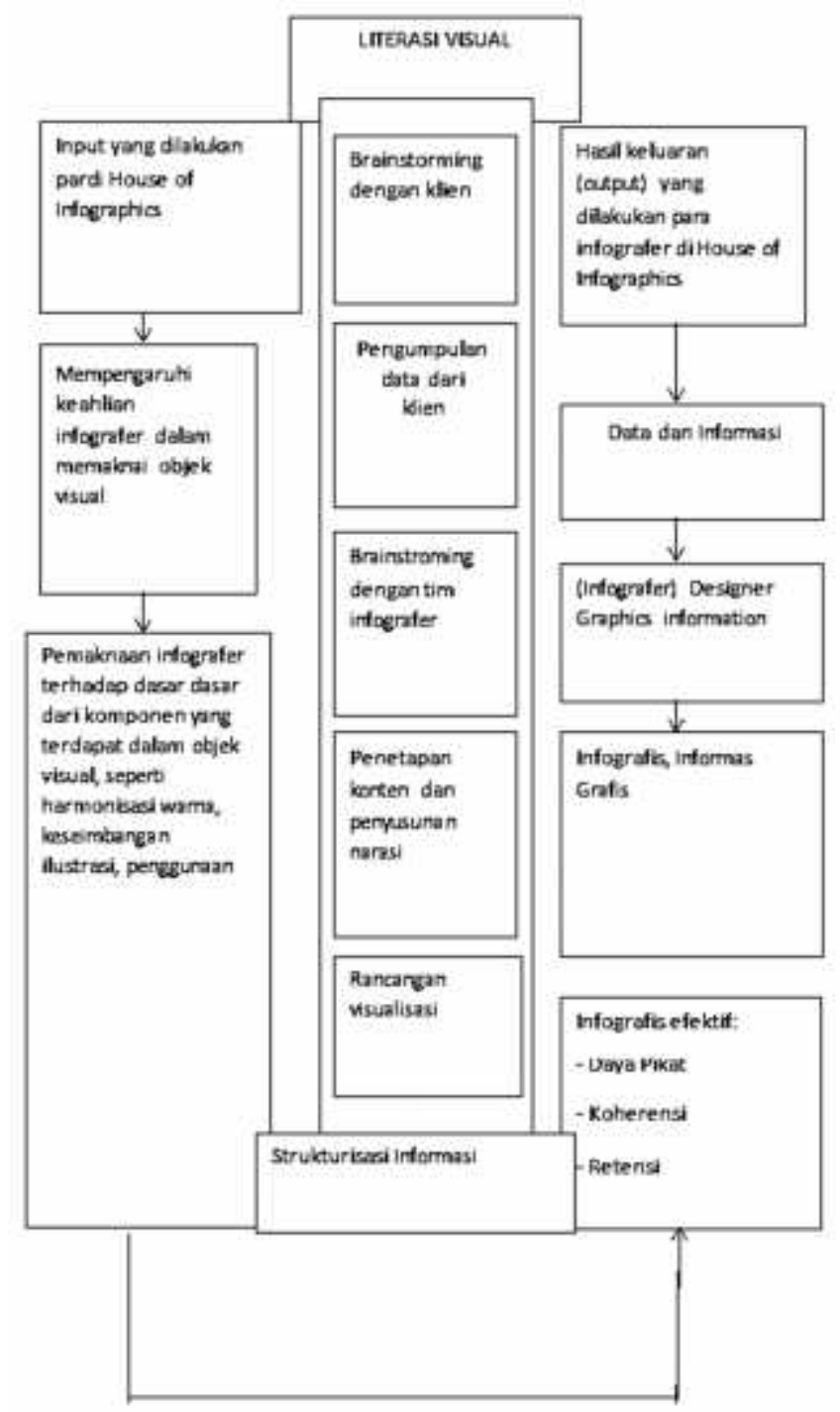

Gambar 1. Visual Infografer di House of Infographics

Sumber: Dari berbagai rujukan dan teori yang diadoptasi peneliti

\section{HASIL DAN PEMBAHASAN}

Dari hasil wawancara yang dilakukan oleh peneliti dengan para infografer, dapat diperoleh proses membaca yang selama ini dilakukan oleh para infografer di House of Infographics tergambarkan bahwa secara garis besar aktifitas membaca merupakan pemrosesan verbal-visual yang dilakukan oleh infografer untuk nantinya difungsikan kembali sebagai alat dalam mengenali kembali objek visual yang memiliki makna yang bersesuaian. Proses membaca objek visual juga secara langsung merupakan salah satu sistem kerja psikologis yang difokuskan dengan sendirinya untuk mencapai tujuan yang ditentukan oleh pribadi sang pembaca, sehingga infografer sebagai pembaca berhak memilikh objek visual yang ingin dan yang tidak ingin dibaca, hal ini pun berhubungan dengan aspek motivasi dari seorang infografer, sehingga pernyataan mengenai suatu objek visual membentuk dan dibentuk oleh infografer selaku pembaca objek visual.

Seni dalam kegiatan membaca dilakukan karena terpengaruh oleh pekerjaan sehingga nantinya terbentuklah pola konseptual yang dilakukan dalam kegiatan membaca yang merupakan hasil dari proses inderawi dan proses pemahaman terhadap objek bacaan. Oleh karena itu sebagai seorang infografer, mereka harus memiliki motivasi untuk memahami dan membaca rangkaian objek visual, karena nantinya hasil dari proses membaca objek visual ini dapat dijadikan sebagai referensi dalam mengilustrasikan visual dari rangkaian informasi, secara tidak langsung proses membaca yang efektif terdari dari tiga (3) poin dasar yang utama, yakni; mengalami, belajar, dan berpikir.

Dari hasil wawancara yang dilakukan oleh peneliti dalam memperoleh data mengenai aktifitas literasi visual dalam kegiatan pembuatan infografis yang terjadi pada tahapan akhir, maka diperoleh data bahwa dalam penyusunan 
visualisasi untuk infografis, para infografer di House of Infographics mengacu pada patokan strukturisasi informasi. Dimana kegiatan yang dilakukan oleh para infografer dalam menyusun strukturisasi informasi didasarkan pada beberapa keterbatasan yang dimiliki oleh manusia dalam kemampuan melihat diantaranya keterbatasan dalam pemberian fokus dan keterbatasan daya ingat. Sehingga House of Infographics memilih menggunakan strukturisasi informasi agar nantinya informasi yang diinginkan memenuhi tiga ketentuan dasar metode penyampaian informasi secara visual dan verbal seperti daya pikat, komprehensi dan retensi.

Untuk memenuhi ketiga ketentuan dalam metode penyebarluasan informasi, maka para infografer yang bekerja di House of Infographics harus memenuhi prosedur dalam pelaksanaan strukturisasi informasi yang sebelumnya telah ditetapkan oleh lembaga sebagai salah satu acuan dalam perancangan infografis. Nantinya dalam pelaksanaan aktifitas strukturisasi informasi, langkah yang diambil oleh para infografer didasarkan pada tiga aspek diantaranya kepadatan informasi, kompleksitas informasi, serta pengelompokan informasi.

\section{SIMPULAN}

Berdasarkan hasil dari pembahasan penelitian yang disesuaikan dengan fokus penelitian, maka dapat disimpulkan bahwa pola literasi visual para infografer dalam pembuatan informasi grafis (Infografis) di House of Infographics dapat dinyatakan sebagai berikut :
1. Kegiatan infografer House of Infographics dalam menafsirkan objek visual merupakan rangkaian proses aktifitas yang diawali dari keterampilan ataupun strategi yang dilakukan oleh para infografer dalam membaca objek visual, hal ini dapat dilihat dari pemahaman mereka terhadap konsep visual, grafis dan estetika, selain itu pemahaman terhadap komponen objek visual juga dibutuhkan agar para infografer nantinya dapat membuat komposisi karya yang baik dan sesuai dengan pengaturan dari masing masing komponen yang akan membentuk. Pola membaca objek visual yang dimiliki oleh para infografer merupakan hasil dari berbagai faktor yang mempengaruhi aktifitas kehidup lingkungan sekitarnya, dan proses ini tentunya akan terus berlangsung sesuai dengan konsep belajar long life learning. Makin sering infografer diberikan stimulus visual maka, makin bertambah pula pengalaman indera penglihatannya, sehingga pada akhirnya hal tersebut mampu menambah kualitas karya yang dihasilkan nantinya

2. Pola yang dibentuk oleh infografer dalam menciptakan rangkaian infografis dimulai dari pemahaman para infografer dalam menafsirkan target mereka untuk menciptakan infografis efektif yakni harus memenuhi tiga kriteria yaitu daya tarik, koherensi dan retensi, dari ketiga aspek tersebut infografer HOI memiliki pola alur kerja yang tersusun sistematis yang disesuaikan untuk mencapai target mereka 
dalam membuat infografis diantaranya dengan melakukan brainstorming dengan klien, pengumpulan informasi dan data, lalu melakukan brainstorming dengan anggota tim HOI, menetapkan konten, penyusunan narasi, perancangan visualisasi informasi, baru setelah itu publikasi infografis.

\section{DAFTAR PUSTAKA}

Glasgow, D. .. (1994). Information Illustration. Addison : Wesley Publishing Company.

Iriantara, Y. (2009). Literasi Media : Apa, Mengapa, Bagaimana. Bandung : Simbiosa Rekatama Media.
Lankow, J., \& Ritchie, J. (2014). Infografis: Kedahsyatan Cara Bercerita Visual. Jakarta : Gramedia Pustaka Utama.

Moleong, L. J. (2007). Metodologi Penelitian Kualitatif. Bandung: Remaja Rosdakarya.

Petterson, R. (2012). An Information Design: An Introduction . Philadelphia : John Benjamins North America.

Wicandra, O. B. (2001). Memahami Wacana Infografis: Sebuah Kajian Semiotik dengan Kasus Infografis pada Seksi Deteksi Harian Jawa Pos Edisi Bulan Februari-Bulan Oktober 2000-Skripsi. Yogyakarta: Institut Seni Indonesia. 